\title{
Importance of Social Support Within the Nursing Staff on Agitation in Residents With Dementia
}

Citation for published version (APA):

Tan, E. Y. L., de Vugt, M. E., Kohler, S., Verhey, F. R. J., \& Schols, J. M. G. A. (2019). Importance of Social Support Within the Nursing Staff on Agitation in Residents With Dementia. Journal of the American Medical Directors Association, 20(6), 785-786. https://doi.org/10.1016/j.jamda.2019.03.002

Document status and date:

Published: 01/06/2019

DOI:

10.1016/j.jamda.2019.03.002

Document Version:

Publisher's PDF, also known as Version of record

Document license:

Taverne

Please check the document version of this publication:

- A submitted manuscript is the version of the article upon submission and before peer-review. There can be important differences between the submitted version and the official published version of record.

People interested in the research are advised to contact the author for the final version of the publication, or visit the DOI to the publisher's website.

- The final author version and the galley proof are versions of the publication after peer review.

- The final published version features the final layout of the paper including the volume, issue and page numbers.

Link to publication

\footnotetext{
General rights rights.

- You may freely distribute the URL identifying the publication in the public portal. please follow below link for the End User Agreement:

www.umlib.nl/taverne-license

Take down policy

If you believe that this document breaches copyright please contact us at:

repository@maastrichtuniversity.nl

providing details and we will investigate your claim.
}

Copyright and moral rights for the publications made accessible in the public portal are retained by the authors and/or other copyright owners and it is a condition of accessing publications that users recognise and abide by the legal requirements associated with these

- Users may download and print one copy of any publication from the public portal for the purpose of private study or research.

- You may not further distribute the material or use it for any profit-making activity or commercial gain

If the publication is distributed under the terms of Article $25 \mathrm{fa}$ of the Dutch Copyright Act, indicated by the "Taverne" license above, 
Letters to the Editor

\section{Importance of Social Support Within the Nursing Staff on Agitation in Residents With Dementia}

\section{To the Editor:}

Patient characteristics such as gender and severity of dementia are associated with neuropsychiatric symptoms (NPS) in dementia but insufficiently explain differences in the prevalence of NPS between dementia care units, thereby suggesting environmental influences. ${ }^{1}$ Physical environmental factors such as perception of privacy, temperature, and number of residents per unit, as well as psychosocial environmental factors such as higher perception of staffing levels, have been associated with NPS. ${ }^{2-4}$ However, the associations between NPS and job characteristics of nurses, such as job demands, control, and social support, as described in the Job Demands-ControlSupport model, ${ }^{5}$ have been studied less intensively.

The aim of this cross-sectional study was to explore the relation between nurses' job characteristics and the prevalence and severity of NPS, specifically agitation, ${ }^{6}$ in residents with dementia. It was hypothesized that less working experience, lower perceived job autonomy and satisfaction, lower levels of social support, and burnout symptoms are related to higher scores on agitation.

\section{Methods}

Nursing home residents from 3 nursing home organizations in the south of the Netherlands, comprising 22 dementia care units, were included if they were 65 years or older, had a diagnosis of dementia, and had complete data at baseline.

The medical ethical committee of the Maastricht University Medical Center has approved the design of the study (MEC 10-4038). The nursing staff, residents, and their legal representatives provided informed consent.

Resident characteristics and measurements were assessed with instruments filled in by the nursing staff. The primary outcome measure was agitation measured with the Cohen-Mansfield Agitation Inventory (CMAI). ${ }^{7}$

Nurses' demographic information was gathered. Job characteristics were measured using the Maastricht Autonomy Scale, ${ }^{8}$ the Job Content Questionnaire social support subscale, ${ }^{9}$ the Utrecht Burn-Out Scale (UBOS), ${ }^{10}$ and a questionnaire concerning job demands and job satisfaction. ${ }^{8}$

\section{Results}

The study included 182 residents from 22 dementia care units [mean age 83.6 years (standard deviation [SD] 7.7), 141 women

The authors declare no conflicts of interest.
(77\%)]. The mean CMAI score was 40.8 (SD 14.1), 52\% demonstrated physically nonaggressive agitated behavior, 40\% aggressive behavior, and $36 \%$ verbally agitated behavior. The CMAI scores of the residents were obtained by 48 members of the nursing staff with a mean age of 34.7 years (SD 1.7), and 43 of them were women. Their average working experience was 14.7 (SD 1.6) years.

Social support was significantly associated with physical aggression $[P=.006$, odds ratio 0.88 (95\% confidence interval 0.81-0.96)]. Higher scores on nurses' perceived within-team social support was associated with lower presence of physical aggression in residents. This finding remained significant when correcting for working experience, burnout symptoms, and job satisfaction. All other job characteristics were not significantly associated with physical aggression nor with verbal agitation or nonaggressive physical agitation.

\section{Discussion}

The study shows that higher scores of perceived social support from coworkers or supervisors are associated with lower odds of physical aggression measured with the CMAI. Social support from coworkers or supervisors may help to cope with a high workload and increase resilience to cope with agitation. ${ }^{11}$ Conversely, a lack of social support may emphasize a feeling that the individual nurse stands alone in dealing with the situation. Physically aggressive agitation but not verbal agitation was associated with social support, which can be explained by the perception of physical agitation as more distressing, and specifically benefit more from the positive effects of social support. Assuming that agitation may evolve in situations where the resident does not understand the reason for care, working together may prevent aggression, for example, by 1 nurse comforting and distracting the resident while the other nurse provides the care. This may be reflected in 1 of the items of the social support scale: "My supervisor succeeds in organizing people to work together." Taken together, social support may influence the nursing staff's perception of problematic behavior and agitation in particular, and may also influence the way nurses cope with agitation.

The main limitations of this study are that no conclusions can be made about the direction of the association between social support and agitation in this cross-sectional study, and its explorative nature. This study does point to a possible new lead for research on the bidirectional interaction between nursing staff and patients that may lead to both vicious and/or virtuous cycles, where the context of work and team may significantly influence the direction of the cycle.

\section{Conclusion}

Higher scores of perceived social support from coworkers and supervisors within the nursing staff are associated with a lower prevalence of physical aggression. Interventions aimed at improving social support may lead to less physical aggression in residents or a better coping with aggression. However, longitudinal studies are needed to study the direction of this association. 


\section{References}

1. Zuidema SU, de Jonghe JF, Verhey FR, Koopmans RT. Environmental correlates of neuropsychiatric symptoms in nursing home patients with dementia. Int J Geriatr Psychiatry 2010;25:14-22.

2. Bicket MC, Samus QM, McNabney M, et al. The physical environment influences neuropsychiatric symptoms and other outcomes in assisted living residents. Int J Geriatr Psychiatry 2010;25:1044-1054.

3. Tartarini F, Cooper P, Fleming R, Batterham M. Indoor air temperature and agitation of nursing home residents with dementia. Am J Alzheimers Dis Other Demen 2017;32:272-281.

4. Stutte K, Hahn S, Fierz K, Zuniga F. Factors associated with aggressive behavior between residents and staff in nursing homes. Geriatr Nurs 2017;38: 398-405.

5. Johnson JV, Hall EM. Job strain, work place social support, and cardiovascular disease: A cross-sectional study of a random sample of the Swedish working population. Am J Public Health 1988;78:1336-1342.

6. Zwijsen SA, Kabboord A, Eefsting JA, et al. Nurses in distress? An explorative study into the relation between distress and individual neuropsychiatric symptoms of people with dementia in nursing homes. Int J Geriatr Psychiatry 2014;29:384-391.

7. de Jonghe JF, Kat MG. Factor structure and validity of the Dutch version of the Cohen-Mansfield Agitation Inventory (CMAI-D). J Am Geriatr Soc 1996;44: $888-889$.

8. Jonge D. Job Autonomy, Well-Being, and Health: A Study Among Dutch Health Care Workers. Maastricht, the Netherlands: Rijksuniversiteit Limburg; 1995.

9. Pelfrene E, Vlerick P, Mak RP, et al. Scale reliability and validity of the Karasek "Job Demand-Control-Support" model in the Belstress study. Work Stress 2001;15:297-313.

10. Schaufeli WB, Bakker AB, Hoogduin K, et al. On the clinical validity of the Maslach Burnout Inventory and the burnout measure. Psychol Health 2001;16: $565-582$.

11. Tummers GE, Landeweerd JA, van Merode GG. Organization, work and work reactions: A study of the relationship between organizational aspects of nursing and nurses' work characteristics and work reactions. Scand J Caring Sci $2002 ; 16: 52-58$

Eva Y.L. Tan, MD

Alzheimer Centre Limburg, School for Mental Health and Neuroscience (MHeNS), Maastricht University, Maastricht, the Netherlands

Reinier van Arkel Mental Health Institute, LJ's-Hertogenbosch, the Netherlands

Marjolein E. de Vugt, PhD, Sebastian Köhler, PhD,

Frans R.J. Verhey, MD, PhD

Alzheimer Centre Limburg, School for Mental Health and Neuroscience (MHeNS), Maastricht University, Maastricht, the Netherlands

Jos M.G.A. Schols, MD, PhD Alzheimer Centre Limburg, School for Mental Health and Neuroscience (MHeNS), Maastricht University, Maastricht, the Netherlands

Department of Family Medicine and Department of Health Services Research, Caphri, Maastricht, the Netherlands

Frailty Should Not Be a Justification for Not Prescribing Anticoagulation in Older Patients With Atrial Fibrillation

To the Editor:

We have read with great interest the article by Alagiakrishnan et $\mathrm{al}^{1}$ and we fully agree with their conclusion advising physicians to be aware of the association of atrial fibrillation (AF) with numerous geriatric syndromes. ${ }^{1} \mathrm{AF}$ is the most common cardiac rhythm disorder in older adults. In subjects aged $>75$ years, AF has been associated with a worse prognosis compared to younger patients, with higher mortality and greater adverse cardiac events rate. ${ }^{2}$ Frailty is a biological state of increased vulnerability to health stressors that is also closely related to the ageing process. Moreover, AF has been associated with frailty, regardless of sex, age, or comorbidities. ${ }^{3}$ So, their association in the daily clinical practice is extremely frequent.

Alagiakrishnan et $\mathrm{al}^{1}$ reported that the evidence of the impact of frailty on anticoagulant prescription is conflicting. Our objective is to communicate the partial data of a recent substudy of our investigation group in which we addressed this problem. ${ }^{4}$

The NONAVASC registry is an observational, prospective, multicenter study, conducted in the internal medicine departments of 64 hospitals from all the Spanish regions. Investigators were required to include at least 10 consecutive patients older than 75 years, hospitalized for any reason, with previous nonvalvular AF (NVAF) diagnosis or incident AF at admission, who gave their written informed consent to participate in the registry. ${ }^{5}$ We assessed frailty with the 5item FRAIL Questionnaire, which evaluates a combination of 5 conditions: fatigue, resistance, aerobic activity, illnesses, and loss of weight. ${ }^{6}$ We consider the results as frail (3-5 points), prefrail (1-2 points), and robust ( 0 points) health status. ${ }^{6,7}$

A total of 615 patients were included in the study. The mean age was $85.2 \pm 5.1$ years, $54 \%$ female, and in most cases (89\%) community-dwelling. NVAF had been diagnosed before admission in most of the patients (93\%). The prevalence of frailty was $48 \%$; $42 \%$ of patients were classified as prefrail, and $10 \%$ as robust. Among the 557 participants discharged, 70\% received anticoagulants, $13 \%$ antiplatelets only, and $17 \%$ had no thromboprophylaxis, with no difference by frailty status. Frailty was not a significant predictor of anticoagulant prescription at discharge (odds ratio 0.93, 95\% confidence interval 0.55-1.57). Our results showed a tendency in which the probability of receiving anticoagulants at discharge decreased 0.89 (95\% confidence interval $0.77-1.03$ ) times for each increase of 1 point in the FRAIL score, but it was nonstatistically significant.

In our observational study, frailty was related to worse global health status. It had no impact on antithrombotic prescription, nor was a predictor of AF complications, even though frail subjects had a higher mortality during hospitalization and after 1-year follow-up.

In this scenario of treating frail patients, who often have high comorbidity, it is reasonable to think that a comprehensive geriatric assessment may assist in the decision process about initiating, interrupting, or discontinuing antithrombotic treatments. ${ }^{8}$ The objective should be achieving high rates of treatment with adequate doses of the appropriate drugs for each frail older adult with $\mathrm{AF}^{9,10}$ In our opinion, only those frail $\mathrm{AF}$ subjects with a clearly unfavorable benefit-risk balance, ${ }^{2}$ detected after a careful evaluation, should be excluded for receiving anticoagulants.

\section{References}

1. Alagiakrishnan K, Banach M, Mah D, et al. Role of geriatric syndromes in the management of atrial fibrillation in older adults: A narrative review. J Am Med Dir Assoc 2019;20:123-130.

2. Suárez Fernández C, Formiga F, Camafort M, et al. Antithrombotic treatment in elderly patients with atrial fibrillation: A practical approach. BMC Cardiovasc Disord 2015;15:143.

3. Nguyen TN, Cumming RG, Hilmer SN. The impact of frailty on mortality, length of stay and re-hospitalisation in older patients with atrial fibrillation. Heart Lung Circ 2016;25:551-557. 